\title{
Genetic Assessment of the Shrub Syncepalum dulcificum (SCHUMACH \& THONN.) Daniell in Nigeria Using the Randomly Amplified Polymorphic DNA (RAPD)
}

\author{
Iloh Andrew Chibuzor ${ }^{1 *}$, Orosun Bukola ${ }^{2}$, Akinyele Olukemi Adejoke ${ }^{2}$, \\ Onyenekwe Paul Chidozie ${ }^{1}$ \\ ${ }^{1}$ Biodiversity and Climate Research Laboratory, Biotechnology Advanced Research Centre (BARC), Sheda Science and Technology \\ Complex, Abuja, Nigeria \\ ${ }^{2}$ Department of Forest Resources Management, University of Ibadan, Ibadan, Oyo State, Nigeria
}

\section{Email address:}

chibaziloh@gmail.com (Iloh A. C.), ac.iloh@shestco.gov.ng (Iloh A. C.)

${ }^{*}$ Corresponding author

\section{To cite this article:}

Iloh Andrew Chibuzor, Orosun Bukola, Akinyele Olukemi Adejoke, Onyenekwe Paul Chidozie. Genetic Assessment of the Shrub Syncepalum dulcificum (SCHUMACH \& THONN.) Daniell in Nigeria Using the Randomly Amplified Polymorphic DNA (RAPD). International Journal of Genetics and Genomics. Vol. 4, No. 6, 2016, pp. 45-50. doi: 10.11648/j.ijgg.20160406.11

Received: December 27, 2016; Accepted: January 7, 2017; Published: January 24, 2017

\begin{abstract}
In order to advocate for informed management decisions with regards to endangered species, we assessed genetic diversity and genetic structure in 40 individuals of six natural populations of the shrub Syncepalum dulcificum (SCHUMACH \& THONN.) DANIELL growing in South Western Nigeria. Twelve (12) Random Amplified Polymorphic DNA (RAPD) primers were tested on total genomic DNA extracted from silica gel dried leaves. Bands were then scored for reproducibility and scoring error calculated. Several genetic diversity parameters were then tested using the POPGENE v1.32 software. Five (5) primers produced 227 reproducible and clear RAPD bands of which 47 were polymorphic $(20.7 \%)$. The percentage of polymorphic loci (PPI) within populations ranged from $36 \%$ to $68 \%$. Nei's gene diversity among population (Hs) was 0.03 , while at species level $(\mathrm{Ht})$ was 0.18 . The coefficient of gene differentiation (Gst) among populations was estimated to be 0.83 with a gene flow rate $(\mathrm{Nm})$ of 2.49 showing high genetic diversity within and among populations. The results however indicate a high similarity between the populations as well as close genetic relationship among them. We infer that $S$. dulcificum in Nigeria does not represent a genetically diverse population and this may be accounted for due the plant's its breeding system which is mainly autogamous. This study further suggests an in-situ form of conservation be set up as immediate rescue conservation procedure for the plant.
\end{abstract}

Keywords: DNA Markers, Genetic Diversity, RAPD, Syncepalum dulcificum

\section{Introduction}

When envisaging the effects of environmental effects on plant biodiversity, there is a need to consider understanding the diversity and population genetic structure of threatened biodiversity. It is therefore important to understand genetic variation within and between populations, as it could help in proper conservation planning and execution. Population genetics typically assess neutral genetic variation and provide estimates of genetic diversity and partitioning among a spatial hierarchy [1]. Studies in population genetics can also estimate both contemporary and historic gene flow, and thereby aid in elucidating past intra-species relationships and distributions as it had been affected by climatic conditions [2]. Such genetic data, coupled with palaeo-ecological data can provide inferences to historical changes in plant biogeography and postglacial expansion/contraction [3], [4], [5]. Furthermore, low genetic diversity may reduce the potential of species or populations to survive in a changing environment [6]. Thus, it becomes imperative to take effective measures to protect these species against further loss especially in our changing world.

Determining the extant and pattern of genetic variation in 
rare plants will promote more informed management decisions with regard to species maintenance, population augmentation, and potential translocation. Research may identify unique variants that warrant greater protection; conversely, research may identify populations sufficiently homogeneous (e.g., clonal) that reductions in population size will not impact viability. Finally, evaluating the risks associated with hybridization in rare plant populations will lead to a greater awareness of how to effectively manage these species in ecological zones that include widespread congeners [6].

Synsepalum dulcificum commonly known as miracle fruits/ berry is a shrub of the family Sapotaceae [7]. The fruit is native to tropical Westand Central Africa: Cameroon, Congo, Gabon, Zaire, Benin, Ghana and Nigeria. Opeke, [8] reported that it is commonly found growing in the wild in fringes of virgin forest as well as naturally in farms and secondary bushes. Achigan-Dako [9] describes the plant as a very promising species but unfortunately poorly documented resource. However, the species is well known for its taste modifying property and this has been traditionally exploited for centuries in Africa. For instance, in Benin republic, the fruit is eaten to aid consummation of tart or sour foods by the locals [9]. The utilization of the taste modifying property of the pulp and pigments in the food industry as well as its medicinal properties and use reported in the treatment of diabetes, malaria, hyperthermia; and enuresis whereas the almond is used to treat stomach ache, anaemia, and obesity [10].

Sadly, the knowledge on genetic improvement potential $S$. Dulcificum is still scanty; As the knowledge on the reproductive biology and mating system is still narrow [9]. Thus, the lack of knowledge of its distribution, genetic variation, will play a significant constraint for conservation programmes. In addition to this, short-lived or recalcitrant seeds often pose great challenges to the plants survival and existence. Hence, to fully understand these potential problems, estimates on the genetic diversity of populations are necessary to discern any problems and stimulate measures, such as cultivation, agro-forestry practices, conservation efforts, and population restoration in the wild [11].

Studies on genetic diversity within populations have been simplified by the introduction of molecular analysis techniques, such as randomly amplified polymorphic DNA (RAPD) analysis [12], [13]. This fingerprinting technique can be used for determining genetic relationships of various species [14], [15], [16]. In addition, RAPD analyses are efficient, economical andtend to produce genetic markers suited to the assessment of population, race and speciesspecific genetic variation [17]. As molecular studies are fast becoming a tool in forest genetic diversity studies, we report the Randomly Amplified Polymorphic DNA (RAPD) assessment of the tree species: Syncepalum dulcificum in Nigeria. Our study hopes to quantify the genetic variation within and between populations (ii) to analyse the geographic distribution of diversity in the natural range, and (iii) to define a conservation strategy based on diversity patterns of the species.

\section{Materials and Methods}

\subsection{Plant Material Collection}

Fresh leaf tissues of Syncepalun dulcificum were collected from six locations (Ijebu-Ode, Forest Resources Management University of Ibadan botanical garden, Cocoa Research Institute of Nigeria (CRIN), National Centre for Genetic Resources and Biotechnology, Alonge village (Onigambari Forest Reserve) all in the South-western part of Nigeria. In total, 40 individuals representing six populations were investigated; with 2-4 individuals per population (Table 1). At least one herbarium specimen was prepared from each locality. Herbarium specimens are deposited in the University of Ibadan Herbarium. The coordinates for the field-collected material were obtained using a handheld GPS unit, and for all kinds of the geographical presentation, ArcView-ArcGIS v10.1 (ESRI, USA) was used.

Table 1. Sample collection, location and geo-references of Syncepalum dulcificum across South West Nigeria.

\begin{tabular}{|c|c|c|c|c|}
\hline Location & Sample Name & Latitude & Longitude & Elevation (m) \\
\hline \multirow[t]{6}{*}{ Ijebu-Ode } & A-E & $003^{\circ} 56.826^{\prime} \mathrm{N}$ & $06^{\circ} 50.972^{\prime} \mathrm{E}$ & 111.9 \\
\hline & $\mathrm{F}$ & $003^{\circ} 56.917^{\prime} \mathrm{N}$ & $06^{\circ} 51.043^{\circ} \mathrm{E}$ & 110.4 \\
\hline & G & $003^{\circ} 56.931^{\prime} \mathrm{N}$ & $06^{\circ} 51.057^{\prime} \mathrm{E}$ & 109.4 \\
\hline & $\mathrm{H}$ & $003^{\circ} 56.930^{\prime} \mathrm{N}$ & $06^{\circ} 51.058^{\prime} \mathrm{E}$ & 112.0 \\
\hline & I & $003^{\circ} 56.939^{\prime} \mathrm{N}$ & $06^{\circ} 51.066^{\prime} \mathrm{E}$ & 110 \\
\hline & $\mathrm{J}$ & $003^{\circ} 56.936^{\prime} \mathrm{N}$ & $06^{\circ} 51.062^{\prime} \mathrm{E}$ & 111.2 \\
\hline \multirow[t]{2}{*}{ Botanical garden } & B-H & $003^{\circ} 53.779^{\prime} \mathrm{N}$ & $07^{\circ} 27.464^{\prime} \mathrm{E}$ & 205 \\
\hline & I-J & $003^{\circ} 53.773^{\prime} \mathrm{N}$ & $07^{\circ} 27.476^{\prime} \mathrm{E}$ & 205 \\
\hline \multirow[t]{2}{*}{ Forestry Research Institute of Nigeria (FRIN) } & A-B & $003^{\circ} 51.742^{\prime} \mathrm{N}$ & $07^{\circ} 23.603^{\prime} \mathrm{E}$ & 209 \\
\hline & $\mathrm{C}$ & $003^{\circ} 51.757^{\prime} \mathrm{N}$ & $07^{\circ} 23.608^{\prime} \mathrm{E}$ & 209 \\
\hline Cocoa Research Institute of Nigeria (CRIN) & A & $003^{\circ} 51.100^{\prime} \mathrm{N}$ & $07^{\circ} 12.457^{\prime} \mathrm{E}$ & 92 \\
\hline National Centre for Genetic Resources and Biotechnology & A-F & $003^{\circ} 50.293^{\prime} \mathrm{N}$ & $07^{\circ} 23.189^{\prime} \mathrm{E}$ & 195 \\
\hline \multirow[t]{2}{*}{ Alonge village (Onigambari Forest Reserve) } & A-B & $003^{\circ} 52.851^{\prime} \mathrm{N}$ & $07^{\circ} 10.626^{\prime} \mathrm{E}$ & 174 \\
\hline & C-D & $003^{\circ} 52.836^{\prime} \mathrm{N}$ & $07^{\circ} 10.634^{\prime} \mathrm{E}$ & 176 \\
\hline
\end{tabular}




\subsection{DNA Isolation}

Total genomic DNA was extracted from silica gel dried leaf tissue. Extraction of total genomic DNA followed the CTAB procedure of Doyle and Doyle, [18] with the following modifications: $700 \mu \mathrm{l}$ of CTAB buffer were used for initial incubation, $500 \mu \mathrm{l}$ of isopropanol were used for DNA precipitation with two subsequent washing steps using $100 \mu \mathrm{l}$ of $70 \%$ ethanol each. Finally, DNA was dissolved in $200 \mu \mathrm{l} 1 \mathrm{x} \mathrm{TE}$ including $2 \mu \mathrm{RNase}\left(10 \mathrm{mg} \cdot \mathrm{ml}^{-1}\right)$.

\subsection{Randomly Amplified Polymorphic DNA (RAPD) Analysis}

Twelve (12) RAPD primers (Eurofins MWG Operon, Germany) were pre-screened in tree replicates in order to select the best markers for further RAPD analysis of $S$. dulcificum. RAPD band reproducibility and scoring error were evaluated using the methods as described by Skroch and Nienhuis [19]. The final Polymerase chain reaction (PCR) protocol for the test samples was carried out in a volume of $28 \mu \mathrm{l}$ containing $20 \mu \mathrm{l}$ Dream master mix (Thermo Scientific, Lithuania) containing $10 \mathrm{x}$ buffer $\left[\begin{array}{ll}10 & \mathrm{Mm}\end{array}\right.$ TrisHCl], $2 \mathrm{mM} \mathrm{MgCl}_{2}, \quad 500 \mu \mathrm{M}$ deoxynucleotide triphosphates (dNTPs), 0.5 units of Taq DNA polymerase, 1 $\mu \mathrm{l}$ bovine serum albumin (BSA) (Thermo Scientific, Lithuania). $2 \mu l$ primer and $5 \mu$ l of total genomic DNA was also added to the PCR cocktail. This screening was repeated three times to check reproducibility of the primer sets.

Modifying the methods of Qadir et al. [20], PCR reactions was performed on Peltier- based Thermal Cycler (LABKITS, Hong Kong.), with initial denaturation of 3 min at $94^{\circ} \mathrm{C}$ followed by 40 cycles of denaturation at $94^{\circ} \mathrm{C}$ for $1 \mathrm{~min}$, annealing at $40^{\circ} \mathrm{C}$ for $1 \mathrm{~min}$ and extension at $72^{\circ} \mathrm{C}$ for $1 \mathrm{~min}$, followed by a final extension for $10 \mathrm{~min}$ at $72^{\circ} \mathrm{C}$.

The amplified products were separated in $1 \%$ agarose gel electrophoresis using 1X TBE buffer stained with GR Green and Visualized on gel documentation system (Flour Shot LAB-KITS, Hong Kong). The molecular size of the amplification products was estimated using $1 \mathrm{~kb}$ DNA ladder (Biolabs, New England). The number of monomorphic bands, number of polymorphic bands and intensity of bands were recorded.

\section{Data Analysis}

To create a binary matrix, amplified fragments of 500$3000 \mathrm{bp}$ were scored visually as having present (1), or absent (0) peaks in the output traces. Only distinct peaks were scored as present, and the manual scoring procedure was repeated many times on separate occasions to reduce scoring errors. The similarity index was calculated from the data using the Nei similarity index coefficient [21]. Taking the Hardy-Weinberg (HW) principle to be at equilibrium, all genetic diversity parameters were calculated using the POPGENE v1.32 software [22].

\section{Results}

\subsection{RAPD Marker Selection}

RAPD was performed in triplicate using genomic DNA to test the reproducibility by checking the pattern of RAPD profiles of each sample. Five primers, OPA-02, OPD-01, OPJ-02, OPL-01 and OPJ-01 (Table 2) produced clear and reproducible polymorphic fragments in all samples, and all of the primers detected significant polymorphisms in the genomic DNA analysis.

Table 2. List of RAPD Primers and their sequences used for the reactions.

\begin{tabular}{lll}
\hline $\mathbf{S} / \mathbf{N}$ & Primer & Sequence5'-3' \\
\hline 1 & OPA 02 & TGCCGAGCTG \\
2 & OPD 01 & ACCGCGAAGG \\
3 & OPJ 02 & CCCGTTGGGA \\
4 & OPL 01 & GGCATGACCT \\
5 & OPJ 01 & CCCGGCATAA \\
\hline
\end{tabular}

\subsection{Diversity Estimates}

Nei's genetic variation statistics for all loci within population is represented in Table 3. Gene diversity (h) ranges from 0.12 to 0.18 Shannon's information index (I) also ranged between 0.19 to 0.28 . In ranking, genetic diversity is rated as follows; $0.12,0.15,0.16$ and 0.18 . Percentage polymorphic loci (PPI) within populations ranged from 36 to 68 . Nei's gene diversity among all populations (Hs) were 0.03 while at species level (Ht) it was 0.18 .

Table 3. Nei's Generic Variation Statistics for All Loci per population of S. dulcificum across South West Nigeria.

\begin{tabular}{|c|c|c|c|c|c|c|c|c|}
\hline $\mathbf{S} / \mathbf{N}$ & Population & Sample Size & na* & $n e^{*}$ & h* & $I^{*}$ & No of PPI & \% PPI \\
\hline 1 & Alonge & 4 & $1.40 \pm 0.50$ & $1.25 \pm 0.33$ & $0.15 \pm 0.19$ & $0.22 \pm 0.28$ & 10 & 40 \\
\hline 2 & CRIN & 3 & $1.36 \pm 0.49$ & $1.20 \pm 0.30$ & $0.12 \pm 0.17$ & $0.19 \pm 0.26$ & 9 & 36 \\
\hline 3 & FRIN & 3 & $1.48 \pm 0.51$ & $1.31 \pm 0.38$ & $0.18 \pm 0.20$ & $0.27 \pm 0.30$ & 12 & 48 \\
\hline 4 & IJEBUODE & 10 & $1.60 \pm 0.50$ & $1.25 \pm 0.32$ & $0.15 \pm 0.17$ & $0.25 \pm 0.25$ & 15 & 60 \\
\hline 5 & NACGRAB & 10 & $1.68 \pm 0.48$ & $1.28 \pm 0.33$ & $0.18 \pm 0.18$ & $0.28 \pm 0.25$ & 17 & 68 \\
\hline 6 & UI & 10 & $1.52 \pm 0.51$ & $1.25 \pm 0.30$ & $0.16 \pm 0.18$ & $0.24 \pm 0.26$ & 13 & 52 \\
\hline
\end{tabular}

*na: Observed number of alleles. * ne: Effective number of alleles. * h: gene diversity. * I: Shannon's Information index. PPI: Polymorphic loci.

\subsection{Genetic Diversity Among Population}

Nei's gene diversity among all population (Hs) 0.03 while at species level (Ht) 0.18 is represented in Table 4 . The coefficient 
of gene differentiation (Gst) among populations was also estimated as 0.83 with a gene flow (Nm) estimate of 2.49.

Table 4. Nei's Analysis of Gene Diversity among populations of S. dulcificum across South West Nigeria.

\begin{tabular}{lllllll}
\hline Sample size & Ht & Hs & $\mathbf{G}_{\text {st }}$ & Nm* $^{*}$ & No of polymorphic loci & \% polymorphic loci \\
\hline 40 & 0.18 & 0.03 & 0.83 & 2.49 & 20 & 80 \\
\hline
\end{tabular}

$* \mathrm{Nm}=$ estimate of gene flow from Gst E.g., $\mathrm{Nm}=0.5(1-\mathrm{Gst}) /$ Gst.

\subsection{Genetic Divergence}

Table 5 shows Nei's genetic distance (D) measured from Nei's unbiased measures of genetic identity and genetic distance. Results show that the highest genetic identity/distance was seen between FRIN and CRIN respectively. The lowest genetic identity/distance was seen between CRIN and Alonge.

Table 5. Nei's Original Measures of Genetic Identity (above diagonal) and Genetic distance (below diagonal) of S. dulcificum across South West Nigeria.

\begin{tabular}{lllllll}
\hline Pop ID & Alonge & CRIN & FRIN & IJEBUODE & NACGRAB & UI \\
\hline Alonge & $* * * *$ & 0.9907 & 0.9292 & 0.9695 & 0.9280 & 0.9588 \\
CRIN & 0.0094 & $* * * *$ & 0.9184 & 0.9725 & 0.9280 & 0.9534 \\
FRIN & 0.0734 & 0.0851 & $* * * *$ & 0.9571 & 0.9389 & 0.9652 \\
IJEBUODE & 0.0309 & 0.0279 & 0.0439 & $* * * *$ & 0.9730 & 0.9800 \\
NACGRAB & 0.0747 & 0.0748 & 0.0631 & 0.0274 & $* * * *$ & 0.9691 \\
UI & 0.0421 & 0.0478 & 0.0354 & 0.0202 & 0.0313 & $* * * *$ \\
\hline
\end{tabular}

\section{Discussion}

Kelley, [23] reports that information about genetic variation within an endangered plant species, such as $S$. dulcificum, can assist in conservation efforts for that species and provide future breeders and researchers with additional data to support their work. Genetic variation study carried out on S. dulcificum is necessary and timely as the species is has been reported to be endangered in the wild [24] while cultivation is somewhat problematic [25], [26]. Even though the plant is of high economic and medicinal interest [27], [28].

RAPD analysis has been successfully used for taxonomic and systematic classification, and phylogenetic or genetic diversity studies in plants [29]. The advantages of this technique as reported by Mahmood et al. [30] includes its speed or rapidity, simplicity as well as the requirement for only small amounts of DNA. Lack for any prior genetic information as well as consistency patterns irrespective of the plant source or age are some other advantages [30].

Although RAPD markers have few disadvantages, some of the problems regarding the reproducibility of RAPD data and scoring errors have been addressed [19]. As the standardization of DNA isolation techniques and PCR reaction conditions are keys in limiting errors, the use of intense staining, clearly resolvable bands and unvaried DNA samples have been shown to provide consistent results [31].

In the current RAPD study, all six populations were similar to each other based on the same band patterns that were obtained after RAPD amplification. These matching bands of similar patterns suggest either, that they originated from a common source, or that the technique was not able to detect variation. The RAPD technique is rarely able to discriminate between very closely related genotypes [32], and this could be the case in this study for $S$. dulcificum. A general relationship between autogamous and level of heterozygosity can be attributed to low levels of genetic variation in autogamous (self- pollinated) plants where according to Hamrick [33], are cases of limited movement of genes through pollen, which then results to less differentiation among population.

Genetic diversity within population range between 0.12 0.18 , such a close range in value suggests that $S$. dulcificum germplasm collection does not represent genetically diverse population. This study agrees with the findings of AchiganDako et al. [9] which states that one of the major contributory factors to the immediate degree of polymorphism seen in some plants might be due to some level of autogamous (selfing) breeding system

As reported by Barrett et al. [34], S. dulcificum practice high levels of selfing and thus might have smaller populations because selfing enables individuals to start colonies following dispersal, or to reproduce under conditions of low density. Predominant selfing has a profound effect on the genome, and autogamous species can provide important model systems for investigating the evolutionary consequences of restricted recombination [34].

Igic and Busch, 35] as well as Wright et al. [36] have also reported high rates of selfing to reduces heterozygosity levels, restrict recombination and multiple factors can contribute to reduced diversity in selfing populations, and distinguishing their relative contributions to overall reductions in diversity. Selfing lowers the effective population size up to two folds due to a reduction in the number of effective alleles in a population, this is very possible under neutrality [34]. Reduction in population could also be due to the life span of highly autogamous species which in most cases are short-lived and occupy unpredictable environments [34] hence making their populations more likely to be susceptible to environmental catastrophes leading to local extinctions. Such demographic factors associated 
with small population size may, in part, contribute to higher extinction rates for $S$. dulcificum where low population was observed during collection. Also noticed was the level of gene flow estimate value $(\mathrm{Nm})$ to be 2.49 was high and this according to Morjan and Rieseberg, [37] noted to be attributed to plants with some form of selfing breeding system. It's reported that plants species plant species with such breeding system have considerably lower migration rates than predominantly out-crossers.

\section{Conclusion}

The current work elucidates the usefulness of molecular markers in establishing distinct relationships within and among population where phenotypic expression using morphological methods alone may not be able to determine.

As Syncepalum dulcificum plant is been reported endangered, this study has been able to report the role which its autogamous breeding system may have played in the survival of the plant. Conscious effort needs to be put in place to study more on the reproductive biology and mating systems. There is also a need to improve plant survival via propagation i.e. domestication through controlled cross pollination which will help in exchange of gene between plus trees that might have been identified (improved breeding). Our study also recommends an in-situ form of conservation be set up as immediate rescue conservation procedure for the plant.

\section{Acknowledgements}

We are grateful to the Sheda Science and Technology Complex, Abuja Nigeria for providing the student fellowship to Orosun, Bukola in the Biodiversity and Climate Research Laboratory, Biotechnology Advanced Research Centre (BARC) under the West Africa Agricultural Research Programme (WAAPP) CARGS grant to Dr. Andrew Chibuzor ILOH. We are particularly thankful Miss Ogechi Nweke (Lab manger/Research Fellow) and Mr. Charles Osuji (Senior Lab Technologist) for the lab support.

\section{References}

[1] Godbout, J., Jaramillo-Correa, J. P., Beaulieu, J. and Bousquet, J. (2005). A mitochondrial DNA minisatellite reveals the postglacial history of jack pine (Pinus banksiana), a broad-range North American conifer. Molecular Ecology, 14: $3497-3512$

[2] Jackson, S. T. (2006). Forest genetics in space and time. New Phytology, 171 (1): 1-3.

[3] Magri, D., Vendramin, G. G., Comps, B., Dupanloup, I., Geburek, T., Gomory, D., Latalowa, M., Litt, T., Paule, L., Roure, J. M., Tantau, I., Knaap, W. O., Petit, R. J. and Beaulieu, J. L. (2006). A new scenario for the Quaternary history of European beech population: Paleobotanical evidence and genetic consequences. New Phytology, 171: 199221.
[4] Petit, R. J., Bialozyt, R., Garnier-Gere, P. and Hampe, A. (2004). Ecology and genetics of tree invasions: from recent introductions to Quaternary migrations. Forest Ecological Management, 197: 117-137.

[5] Richardson, B. A., Brunsfeild, S. J. and Klofenstein, N. B. (2002). DNA from bird-dispersed seed and wind disseminated pollens provides insights into postglacial colonization of white-bark pine (Pinusal bicaulis) Molecular Ecology, 11: 215-227.

[6] Qiu, Y. X. and Fu, C. X. (2001). Studies on the endangerment mechanism of and conservation strategies for Changium smyrnioides. China Biodiversity, 9: 151-156.

[7] Keay, R. W. J. (1992). Trees of Nigeria. Clarendon Press, Oxford, United Kingdom.

[8] Opeke, I. K. (1984). Growth and morphogenesis of mature embryo of Capsella in culture. Plant. Physiology, 39: 691-699.

[9] Achigan-Dako., E. G., Tchokponhoué, D. A., N'Danikou, S., Gebauer, J. and Vodouhè, R. S. (2015). Current knowledge and breeding perspectives for the miracle plant Synsepalum dulcificum (Schum. et Thonn.) Daniell. Genetic Resources and Crop Evolution, 62 (3): 465-476.

[10] Oumorou, M., Dah-Dovonon, J., Aboh, B. A., Hounsoukaka, M. and Sinsin, B. (2010). Contribution a' la conservation de Synsepalum dulcificum: regeneration et importance socioeconomique dans le departement de loueme (Benin). Annales de la Science Agronomique, 14: 101-120

[11] Idohou, R., Assogbadjo, A. E., Fandohan, B., Gouwakinnou, G. N., Kakai, R. L. G., Sinsin, B. and Maxted, N. (2013). National inventory and prioritization of crop wild relatives: case study for Benin. Genetic Resources and Crop Evolution, 60: $1337-1352$.

[12] Welsh, J. and McClelland, M. (1990). Fingerprinting genomes using PCR with arbitrary primers. Nucleic Acids Research, 18: 7213-7218.

[13] Williams, J. G. K., Kubelik, A. R., Livak, K. J., Rafalski, J. A. and Tingey, S. V. (1990). DNA polymorphisms amplified by arbitrary primers are useful as genetic markers. Nucleic Acids Research, 18: 6531-6535.

[14] Ramshini, H., Naghavi, M. R. and Alizadeh, H. (2005). Comparison of genetic diversity based on total and sharp bands of RAPD data in wheat. Asian. Journal of Plant Science 4 (2): 123-127.

[15] Hoque, M. O., Topaloglu, O. and Begum, S. (2005). Quantitative methylation- specific polymerase chain reaction gene patterns in urine sediment distinguished prostate cancer patients from control subjects. Journal of Clinical Oncology, 23 (27): 6569-75.

[16] Sadder, M. T. and Ateyyeh, A. F. (2006). Molecular assessment of polymorphism among local Jordanian genotypes of the common Fig (Ficus carica L.). Scientia Horticulturae, 107: 347-351.

[17] Aagaard, J. E., Krutovsku, K. V. and Strauss, S. H. (1998). RAPDs and allozymes exhibit similar levels of diversity and differentiation among population and races of Douglas fir. Heredity, 81: 69-78.

[18] Doyle, J. J. and Doyle, J. L. (1987). A rapid DNA isolation procedure for small quantities of fresh leaf tissue. Phytochemical bulletin, 19: 11-15. 
[19] Skroch, P. and Nienhuis, J. (1995). Impact of scoring error and reproducibility of RAPD data on RAPD based estimates of genetic distance. Theoretical and Applied Genetics, (1995) 91: 1086-1090.

[20] Qadir, A., Ilyas, M., Akhtar, W., Aziz, E., Rasheed, A. and Mahmood, T. (2015). Study of genetic diversity in synthetic hexaploid wheats using Random Amplified Polymorphic DNA. The Journal of Animal and Plant Science, 25 (6): 2015: 1660-1666.

[21] Nei, M. (1978). Estimation of average heterozygosity and genetic distance from a small number of individuals. Genetics, 89: 583-890.

[22] Yeh, F. C., Yang, R. C. and Boyle, T. (1997). POPGENE, a userfriendly shareware for population genetic analysis. Molecular Biology and Biotechnology Centre, University of Calgary, Canada.

[23] Kelley, K. (2009). Genetic Variability in Hydrastis Canadensis L. Using RAPD Analysis. (Dissertation). University of Massachusetts.

[24] Meregini, A. O. A. (2005). Some endangered plants producing edible fruits and seeds in Southeastern Nigeria. Fruits, 60: 211-220. doi:10.1051/fruits:2005028.

[25] Ogunsola, K. E. and Ilori, C. O. (2008). In vitro propagation of miracle berry (Synsepalum dulcificum Daniel) through embryo and nodal cultures. African Journal of Biotechnology 7 (3): $244-24$.

[26] Joyner, G. (2006). "The Miracle Fruit," in Quandong Magazine, ed. Scott, P. West Australian Nut and Tree Crop Association West Australia, pp 15-15.

[27] Edem, C. A., Dosunmu, M. I., Ebong, A. C. and Jones, M. (2008). Determination of proximate composition of ascorbic acid and heavy metal contents of star fruit (Averrhoa Carambola). Global Journal of Pure and Applied Science, 14 (2): 193-195.

[28] Nkwocha, C. (2014). Proximate and composition analyses of Synsepalum dulcificum pulp. Science Research Journal, 2: 7174.
[29] Neog, K., Singh, H., Unni, B. and Sahu, A. K. (2010). Analysis of genetic diversity of muga silkworm (Antheraea assamensis, Helfer; Lepidoptera: Saturniidae) using RAPDbased molecular markers. African Journal of Biotechnology, 9 (12): 1746-1752.

[30] Mahmood, T., Nazar, N., Abbasi, B. H., Khan, M. A., Ahmad, M. and Zafar, M. (2010). Detection of somaclonal variations using RAPD fingerprinting in Silybum marianum (L.). J. Medicinal Plants Research, 4 (17): 1822-1824.

[31] Aruna, M., Ozias-Akins, P., Austin, M. E. and Kochert, G. (1993). Genetic relatedness among rabbit eye blueberry (Vaccinium ashei) cultivars determined by DNA amplification using single primers of arbitrary sequence. Genome, 36 (5): 971-977.

[32] Dettori, M. T. and M. A. Palombi, 2000. Identification of Feijoa sellowiana Berg accessions by RAPD markers. Scientia Horticulturae, 86: 279-90.

[33] Hamrick, J. L. (1983). "The distribution of genetic variation within and among natural plant populations," In, SchonewaldCox, C. M., Chambers, S. M., McBryde, B. and Thomas, W. L. (Eds.) Genetics and Conservation, Benjamin/Cummings, Menlo Park, CA, USA., pp 335-348.

[34] Barrett, S. C. H., Arunkumar, R and Wright, S. I. (2014). The demography and population genomics of evolutionary transitions to self-fertilization in plants. Philosophical Transactions of the Royal Society Biology, 369: 1-9.

[35] Igic, B. and Busch, J. W. (2013). Is self-fertilization an evolutionary dead end? New. Phytology, 198: 386-397.

[36] Wright, S. I., Kalisz, S. and Slotte, T. (2013). Evolutionary consequences of self-fertilization. Proceedings of the Royal Society Biology, 280: 20130133.

[37] Morjan, C. L. and Rieseberg, L. H (2004). How species evolve collectively: Implications on gene flow and selection for the spread of advantageous alleles. Molecular Ecology 13: 1341-1356. 